\title{
Genetic algorithm to improve power output of photovoltaic system under partial shaded condition
}

\author{
Abdalla Eltigani Ibrahim, Nursyarizal Mohd Nor, Illani Binti Mohd Nawi, Mohd Fakhizan Romlie, \\ Khairul Nisak Mohd hasan \\ Department of Electrical \& Electronic Engineering, Universiti Teknologi PETRONAS, Malaysia
}

\begin{abstract}
Article Info
Article history:

Received Apr 15, 2019

Revised Jun 19, 2019

Accepted Jul 16, 2019

\section{Keywords:}

Fuzzy logic controller (FLC)

Genetic algorithm (GA)

Maximum power point tracking

(MPPT)

Partial shaded conditions (PSC)

ABSTRACT

The Partial Shaded Condition (PSC) is a process of non-optimal power capture in photovoltaic (PV) system; it will happen when one or all the PV solar cells get shaded by external factors. This phenomenon makes a sudden change in cell irradiance and lead to non-optimal power capture and reduces the generated power in PV systems. Cell under PSC generates one global peak (GP) and many local peaks (LPs), but the tracking of GP under (PSCs) effectively are still a big challenge to the researchers. In this paper, Fuzzy Logic Control (FLC) and optimized FLC algorithms were developed to track the PV power during the PSCs. The configuration of both algorithms are designed, simulated and evaluated using MATLAB/Simulink and their performance was compared with other literature techniques to study their capability to track the MPPT under PSCs. Proposed GA-FLC achieved 0.7 S as tracking time to find and track the Global Peak of Maximum power Point (GMPP) under PSCs and the usage of buck/boost converter in this technique achieved $98.5 \%$ of tracking accuracy. GA-FLC shows good dynamic performance in terms of tracking accuracy and complexity under PSCs compared to other techniques.
\end{abstract}

Copyright @ 2019 Institute of Advanced Engineering and Science. All rights reserved.

\section{Corresponding Author:}

Abdalla Eltigani Ibrahim,

Department of Electrical \& Electronic Engineering,

Universiti Teknologi PETRONAS,

32610, Seri Iskandar, Perak, Malaysia.

Email: abdotigani11@gmail.com

\section{INTRODUCTION}

Solar photovoltaic (PV) system is one of the most famous and modern technologies ln the world, because it is clean, abundant, noise free, and friendly to the environment compared to other sources [1,2]. The output power (P) with respect to the panel voltage (V) is equal to zero at Maximum Power Point (MPP) in PV systems. The Partial Shaded Condition (PSC) is a process of non-optimal power capture in photovoltaic (PV) system; it will happen when one or all the PV solar cells get shaded by external factors. This phenomenon makes a sudden change in cell irradiance and lead to non-optimal power capture and reduces the generated power in PV systems [3]. Cell under PSC generates one global peak (GP) and many local peaks (LPs), but the tracking of GP under (PSCs) effectively are still a big challenge to the researchers [4-8]. Numerous of MPPT techniques have been classified in tracking the MPPT under PSCs, into traditional algorithms [9-11], intelligent algorithms [12-15] and hybrid algorithms [16-22]. The LPs under PSC can be tracked efficiently and accurately using conventional, soft computing or hyper MPPT algorithms. Whereas, GP under (PSCs) can only be tracked by soft or hyper techniques and tracking speed and efficiency are still a big challenge to the researchers. Therefore, an effective MPPT technique should be carried out to track these peaks effectively and accurately in PV systems. 
Based on Figure 1, the equivalent circuit of a PV model consists of a photocurrent, diode, parallel resistor which represents a leakage current, and series resistor which represents an internal resistance to the current flow.

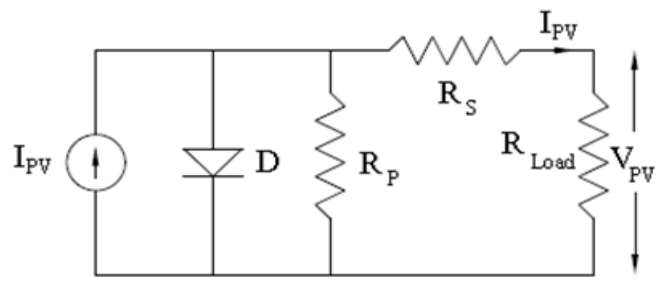

Figure 1. Equivalent circuit of PV cell

The output current equation is given by [23].

$$
I=N_{P} I_{p h}-N_{P} I_{o}\left[\exp \left(\frac{q\left(V_{p v}+I R_{s}\right.}{A K T_{c} N_{s}}\right)-1\right]-\left(\frac{V_{p v}+I R_{s}}{R_{p}}\right)
$$

where $N s$ is the number of series resistance cells, $N_{P}$ is the number of parallel resistance cells and $R_{p}$ is the parallel resistance, which is very high, so, its current can be neglected. The term (1) can be simplified as

$$
I=I_{p h}-I_{o}\left[\exp \left(\frac{q\left(V_{p v}+I R_{s}\right)}{A K T_{c} N_{s}}\right)-1\right]
$$

where $q$ is the electronic charge $\left(q=1.6 \times 10^{-19}\right), k$ is Boltzmann's constant $\left(k=1.38 \times 10^{-23} \mathrm{~J} / \mathrm{K}\right), A$ is the ideal factor of the diode $(\mathrm{A}=1.6), I_{o}$ varies with the change in temperature and is given by

$$
I_{o}=I_{\text {ro }}\left(\frac{T_{c}}{T_{r}}\right)^{3} \exp \left[\left(\frac{q E_{g}\left(1 / T_{r}-1 / T_{c}\right.}{A K}\right)\right]
$$

where $E g$ is the band gap energy of the semiconductor and $I_{r o}$ is the saturation current of the diode at $25^{\circ} \mathrm{C}$, which is calculated by

$$
\mathrm{I}_{\text {ro }}=\frac{\mathrm{I}_{\mathrm{sc}}}{\exp \left[\mathrm{q} \mathrm{U}_{\mathrm{oc}} / \mathrm{AK} \mathrm{T}_{\mathrm{r}} \mathrm{N}_{\mathrm{s}}\right]-1}
$$

where $U_{o c}$ and $I$ sc are the open-circuit voltage and short-circuit current of the PV module at STC $\left(T=25^{\circ} \mathrm{C}\right.$, $\left.S=1000 \mathrm{~W} / \mathrm{m}^{2}\right)$.

$$
\mathrm{I}_{\mathrm{ph}}=\mathrm{I}_{\mathrm{sc}}+\mathrm{KI}\left(\mathrm{T}_{\mathrm{c}}-\mathrm{T}_{\mathrm{r}}\right) \mathrm{G}
$$

where $K I$ is the short-circuit current temperature coefficient of the cell. $T c$ and $T r$ are the cell temperature and the reference temperature, respectively. $G$ is the relative irradiance coefficient under STC [23].

\section{RESEARCH METHODOLOGY}

\subsection{FLC based MPPT structure}

FLC has wide range of PV systems applications, it can play as MPP trcker under PSCs since it has the advantages such as robust, relatively simple to design and it only require the knowledge of the model [16]. In this technique, based on the characteristic of PV panel, a FLC optimized by GA, is proposed to track the MPP of the module under PSC. The process of FLC can be classified into three stages, fuzzification, rule evaluation and defuzzification and it has two inputs and one output. The input and output variables are converted into linguistic variables based on the membership functions of (6), (7), and (8) respectively [16].

$$
\begin{aligned}
& \Delta \mathrm{V}=\mathrm{V}_{(\mathrm{K})}-\mathrm{V}_{(\mathrm{K}-1)} \\
& \Delta \mathrm{P}=\mathrm{P}_{(\mathrm{K})}-\mathrm{P}_{(\mathrm{K}-1)}
\end{aligned}
$$




$$
\mathrm{D}=\frac{\sum_{\mathrm{j}=1}^{\mathrm{n}} \mu\left(\mathrm{D}_{\mathrm{j}}\right)-\mathrm{D}_{\mathrm{j}}}{\sum_{\mathrm{j}=1}^{\mathrm{n}} \mu\left(\mathrm{D}_{\mathrm{j}}\right)}
$$

The inputs are the change in the voltage of the PV panel $(\Delta \mathrm{V})$, change in the power $(\Delta \mathrm{P})$ and the output variable is duty cycle. Five fuzzy levels are used for inputs and outputs variables: NB (negative big), NS (negative small), ZE (zero), PS (positive small), and PB (positive big) as shown in Figure 2. The MFs of the input variables; both $\Delta \mathrm{P}$ and $\Delta \mathrm{V}$ MFs are in triangular form and the MF of the output (duty cycle step size $\Delta \mathrm{D}$ ), which is also in triangular form.

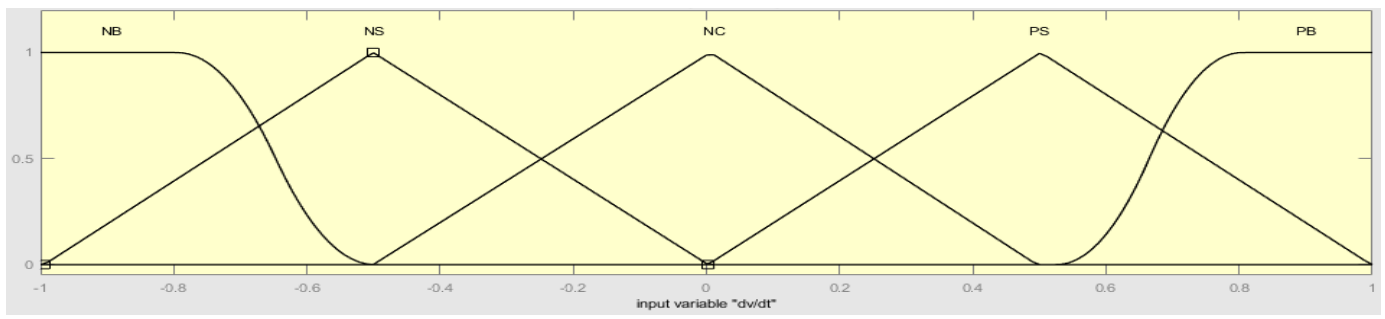

(a)

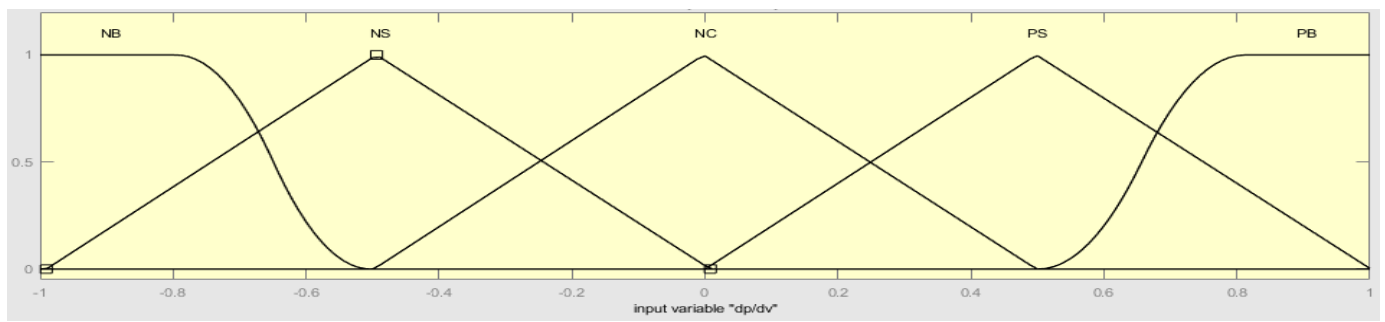

(b)

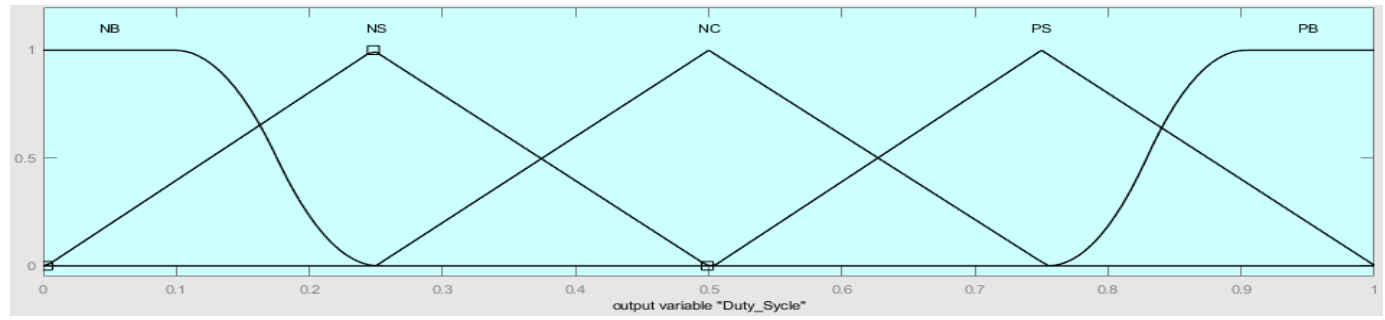

(c)

Figure 2. The Membership function of the input variable (a) $(\Delta \mathrm{V}),(\mathrm{b})(\Delta \mathrm{P})$ and output variable $(\Delta \mathrm{D})$

The maximum power in the P-V curve of PV cell can be obtained when $|\Delta \mathrm{P} / \Delta \mathrm{V}|$ equal to zero. As shown in Figure 3, the operating point can be moved from right to left along the $P-V$ curve, therefore, the algorithm has to add a large $\triangle \mathrm{D}$ to reach the MPP if the point in $\mathrm{A}$ or $\mathrm{B}$, or adding a smaller $\Delta \mathrm{D}$ to reach the MPP if the operating point in $\mathrm{C}$ or $\mathrm{D}$. The signal of $\Delta \mathrm{D}$ depends on the operating point in the PV curve, for example if the operating point in the right side of MPP (point D or B), the $\triangle \mathrm{D}$ will be positive value and if the operating point in the left side of MPP (point $\mathrm{A}$ or $\mathrm{C}$ ), the $\triangle \mathrm{D}$ will be negative value. Based on this concept, a complete set of fuzzy rules for the proposed FLC are summarized in Table 1. 


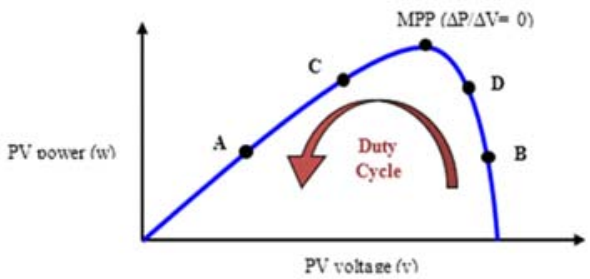

Table 1. Memberships rules used in the FLC

\begin{tabular}{|c|c|c|c|c|c|}
\hline & \multicolumn{5}{|c|}{$\Delta \mathrm{P}$} \\
\hline \multirow{5}{*}{$\Delta \mathrm{V}$} & $\mathrm{ZE}$ & NS & PS & PS & PS \\
\hline & ZE & ZE & ZE & ZE & ZE \\
\hline & PS & ZE & NS & ZE & NS \\
\hline & PS & PS & ZE & NS & NS \\
\hline & PB & NS & PB & NB & NS \\
\hline
\end{tabular}

Figure 3. Proposed MPPT technique in $P-V$ curve

\subsection{Genetic optimization steps of FLC}

To improve FLC's tracking speed; GA was implemented to obtain the optimal FLC membership functions. This is achieved according to the following stages:

\subsubsection{The optimization criterion}

The quadratic criterion to be minimized is [16].

$$
J=\int_{0}^{\infty} e^{2}(t) d t
$$

Where

$$
e(t)=V_{(\text {Max }) \text { expected }}(t)-V_{(\text {Max }) P V}(t)
$$

$V_{(\text {Max } P V}$ is the instant tracked voltage which was given by PV module under STC.

The relations and the values between $\mathrm{Ci}, \mathrm{Ci}^{\prime} \mathrm{Ci}^{\prime \prime}$, and $x i, y i$, zi are respectively given by

$$
\left\{\begin{array}{l}
x_{1}=C_{4}+C_{3}, x_{2}=C_{3} \\
x_{3}=C_{1}, x_{4}=C_{1}+C_{2}
\end{array}\right\}\left\{\begin{array}{l}
y_{1}=C_{4}{ }^{\prime}+C_{3}{ }^{\prime}, y_{2}^{\prime}=C_{3}{ }^{\prime} \\
y_{3}=C_{1}{ }^{\prime}, y_{4}=C_{1}{ }^{\prime}+C_{2}{ }^{\prime}
\end{array}\right.
$$

\subsubsection{Creation of the initial population}

In the design of the proposed GA-FLC, two inputs, $V(k), P(k)$, and one output, $D$, are used. Each variable is described with five membership functions, as illustrated in Figure 4 (a). The population has a set of individuals, each individual has three chromosomes: $\Delta V(k), \Delta P(k)$ and $D$ as shown in Figure $4(b)$ and described by:

- For the chromosome $\Delta V(\mathrm{k})$ the genes: C1,C2,C3,C4 in variation [-0.99 to +0.99$]$.

- For the chromosome $\Delta P(k)$ the genes: $\mathrm{C}^{\prime}, \mathrm{C} 2$ ', $\mathrm{C} 3$ ', $\mathrm{C} 4$ ' in variation [-0.99 to +0.99$]$.

- For the chromosome $D$ the genes are: C1", C2", C3", C4" in variation [-0.99 to +0.99].

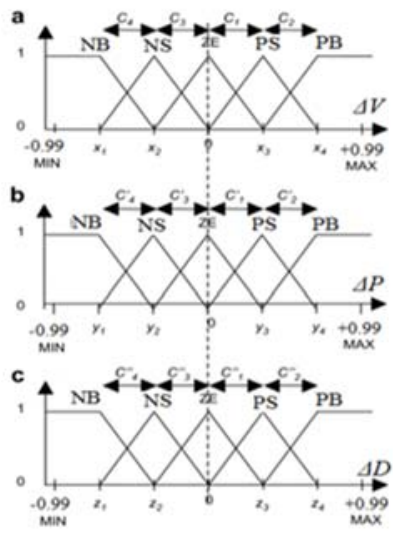

(a)

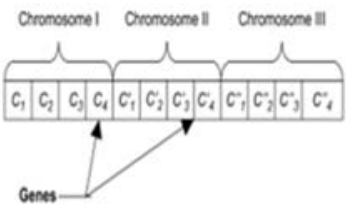

(b)

Figure 4. (a) Memberships function coding $\Delta V, \Delta P$ and $\Delta D$, (b) Description of an individual

Genetic algorithm to improve power output of photovoltaic system under ... (Abdalla Eltigani Ibrahim) 


\section{RESULTS AND ANALYSIS}

\subsection{Effect of the irradiance and temperature on PV system}

Depending on Figure 5, the PV module was designed using modeling terms (1), (2), (3), (4) and (5) which are discussed in section 1 . The module has three inputs: radiation intensity, voltage and operation temperature, and two outputs: voltage and current (power can be obtained by multiply voltage in current). The MPPT was designed using GA-FLC. The input voltage was adjusted to $24 \mathrm{~V}$, the radiation adjusted to $1000 \mathrm{~W} / \mathrm{m}^{2}$ and the operation temperature was adjusted to three values $\left(25^{\circ} \mathrm{C}-50^{\circ} \mathrm{C}-75^{\circ} \mathrm{C}\right)$.

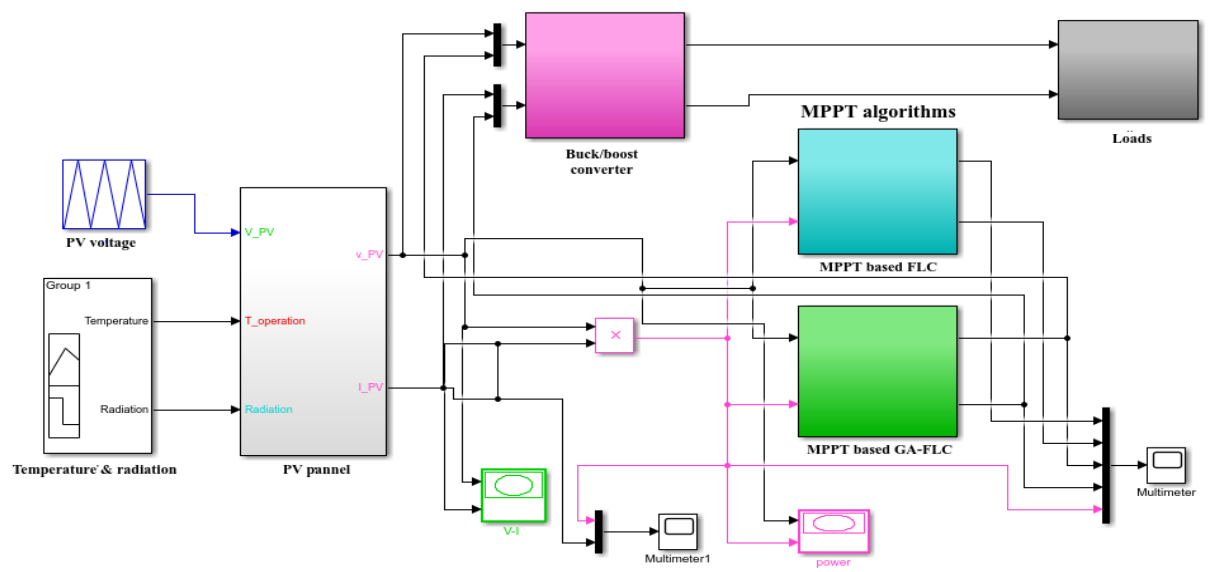

Figure 5. PV module under PSCs with MPPT algorithms in Simulink MATLAB

To discover the effect of temperature on the solar PV performance, solar irradiation level was assumed constant at $1000 \mathrm{~W} / \mathrm{m}^{2}$ while allowing temperature to vary between $0{ }^{\circ} \mathrm{C}$ and $75{ }^{\circ} \mathrm{C}$ and the result is shown in Figure 6 (a), for the I-V and P-V characteristics as temperature was set to 25,50 and $75{ }^{\circ} \mathrm{C}$ respectively. The cell voltage decreases as operating temperature increases and output power decreases. This indicates that operating temperature can affect on both voltage and power output of the solar panel significantly. Figure 6 (b) shows the changes in open-circuit voltage and current of PV panel when a panel temperature increases. When operating temperature is increased, the current decreases and the voltage increases. This indicates that, temperature of the PV panels can affect in both efficiency and power output of the solar panel.

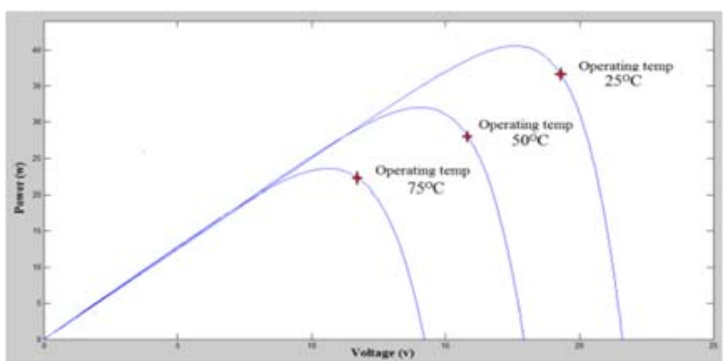

(a)

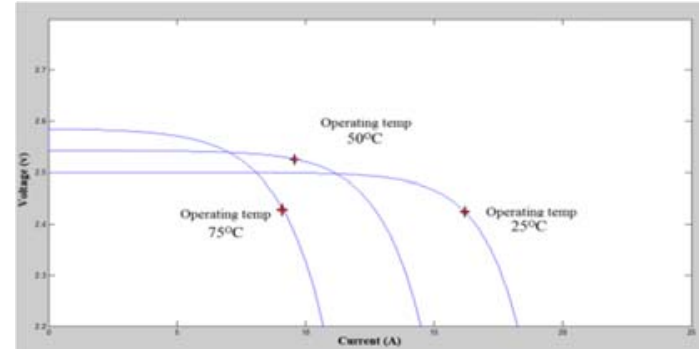

(b)

Figure 6. (a) $\mathrm{P}-\mathrm{V}$ curve under temperature changes, (b) I-V curve under temperature changes

\subsection{Performance of the proposed MPPT based GA-FLC}

Figure 7 (a) shows the performance of proposed MPPT based FLC and GA-FLC to the fast change during PSCs. The results proved that, when radiation changes happened during PSCs, the MPPT algorithm based GA-FLC responded faster than FLC to overcome power decreasing in the solar panel. The response time of GA-FLC is about $0.7 \mathrm{~S}$ and for FLC is about $1.75 \mathrm{~S}$. Based on Figure 7 (b), when power of PV panel dropped down by PSCs both FLC and GA-FLC algorithms overcome this dropping, but the overcome of optimized FLC is bigger than FLC. Also, in Figure 7 (c), when generated power by PV cell was dropped, 
both FLC and optimized FLC algorithms discharged power from the battery to overcome this dropping and this case, the performance of optimized FLC is better than FLC, but the tracking speed needs more analysis and discussions in real time experiment under different atmospheric conditions.

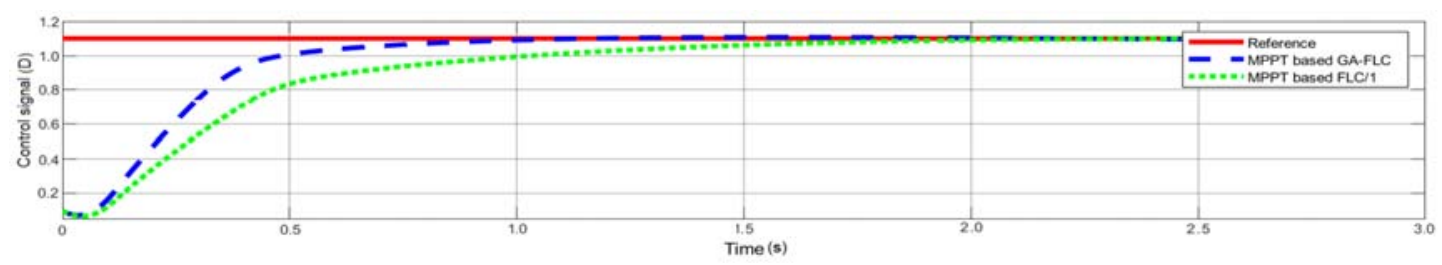

(a)

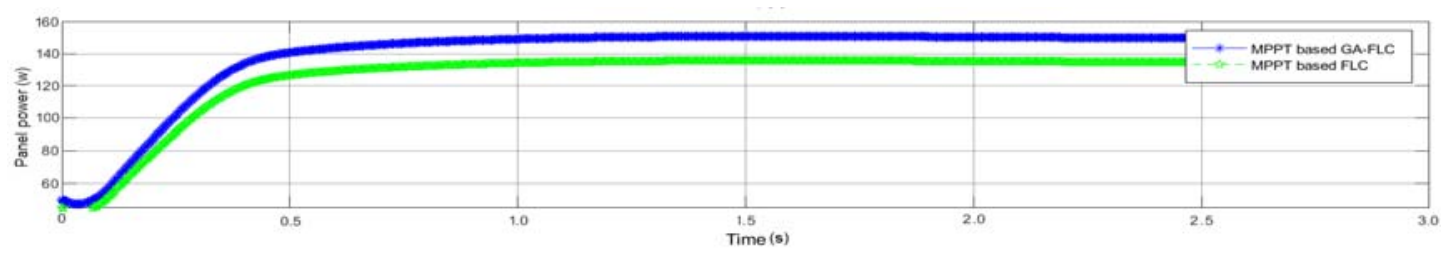

(b)

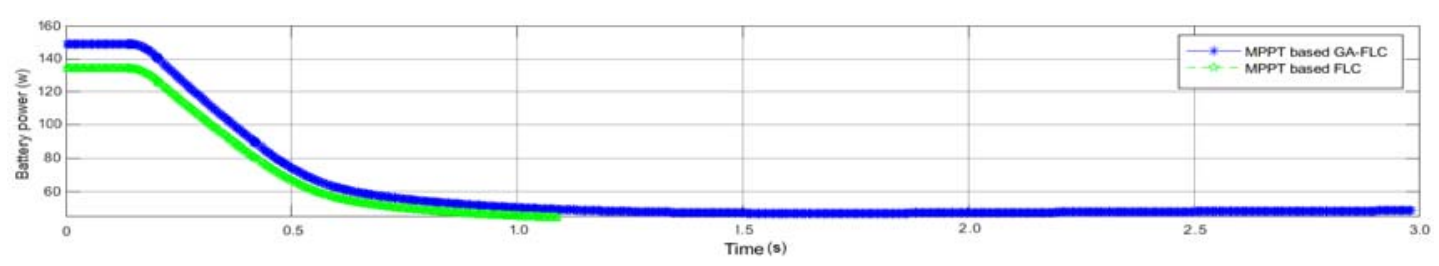

(c)

Figure 8. (a) Response of the MPPT based FLC and GA-FLC to the PSCs change, (b) response of proposed algorithms to the discharge in PV panel during PSCs change; (c) response of proposed algorithms to the overcharge in the battery of PV panel during PSCs change

Table 2 shows the results obtained from proposed GA-FLC algorithm under PSCs compared to other MPPT techniques under PSCs in literature review. The results proved that, the proposed GA-FLC is the most efficient algorithm to find and track GMPP in terms of accuracy, tracking speed and complexity under PSCs comparing to other techniques such as FLC, GA-P\&O and ANN-FLC.

Table 2: Results of proposed GA-FLC compared to other MPPT techniques under PSCs

\begin{tabular}{ccccccc}
\hline Refference & Year & $\begin{array}{c}\text { MPPT } \\
\text { technique }\end{array}$ & Converter & Accuracy \% & $\begin{array}{c}\text { Tracking } \\
\text { speed (s) }\end{array}$ & $\begin{array}{c}\text { Level of technique } \\
\text { Complexity }\end{array}$ \\
\hline$[24]$ & 2014 & GA-P\&O & Buck & 95.5 & 0.9 & High \\
{$[22]$} & 2009 & ANN-FLC & Boost & 92.1 & 0.85 & High \\
{$[25]$} & 2018 & GA-FLC & Boost & 95 & - & High \\
{$[16]$} & 2012 & FLC & Buck/boost & 86 & 1.75 & Low \\
Prposed MPPT & 2019 & GA-FLC & Buck/boost & 98.5 & 0.7 & Medium \\
\hline Prposed MPPT & 2019 & G.5 & & & &
\end{tabular}

\section{CONCLUSION}

In this paper, FLC and optimized FLC algorithms were developed to track the PV power during the PSCs. The configuration of both algorithms is designed, simulated and evaluated using MATLAB/Simulink and their performance was compared with other literature techniques to study their capability to track the MPPT under PSCs. Proposed GA-FLC achieved 0.7 S as tracking time to find and track the GMPP under

Genetic algorithm to improve power output of photovoltaic system under ... (Abdalla Eltigani Ibrahim) 
PSCs and the usage of buck/boost converter in this technique achieved $98.5 \%$ of tracking accuracy. The tracked power of PV systems under PSC is affected directly by the tracking speed and any delay in tracking time affects in efficiency of a whole system. The obtained results proved that, proposed GA-FLC showed good dynamic performance in terms of tracking time, accuracy and complexity under PSCs compared to other techniques such as FLC, GA-P\&O and ANN-FLC. For the future work, the performance of proposed optimized FLC needs to be validated by experimental test. Furthermore, the tracking speed needs more analysis and discussions under different atmospheric conditions.

\section{REFERENCES}

[1] N. Izzati, A. Aziz, S. Irwan, S. Shaari, I. Musirin, and K. Sopian, "Optimal sizing of stand-alone photovoltaic system by minimizing the loss of power supply probability," Sol. Energy, vol. 150, pp. 220-228, 2017.

[2] Z. Othman, S. I. Sulaiman, I. Musirin, A. M. Omar, S. Shaari, and M. Z. Rosselan, "Sizing Optimization of Hybrid Stand Alone Photovoltaic System,” Int. J. Adv. Sci. Eng. Inf. Technol., vol. 7, no. 6, pp. 1991-1997, 2017.

[3] M. A. M. Ramli, S. Twaha, K. Ishaque, and Y. A. Al-turki, "A review on maximum power point tracking for photovoltaic systems with and without shading conditions," Renew. Sustain. Energy Rev., vol. 67, pp. 144-159, 2017.

[4] K. Ishaque, Z. Salam, and H. Taheri, "Modeling and simulation of photovoltaic (PV) system during partial shading based on a two-diode model," Simul. Model. Pract. Theory, vol. 19, no. 7, pp. 1613-1626, 2011.

[5] K. Ishaque, Z. Salam, and G. Lauss, "The performance of perturb and observe and incremental conductance maximum power point tracking method under dynamic weather conditions," Appl. Energy, vol. 119, pp. 228-236, 2014.

[6] F. L. Tofoli, D. De Castro Pereira, and W. J. De Paula, "Comparative study of maximum power point tracking techniques for photovoltaic systems," Int. J. Photoenergy, vol. 2015, no. i, 2015.

[7] K. Sundareswaran, P. Sankar, P. S. R. Nayak, S. P. Simon, and S. Palani, "Enhanced energy output from a PV system under partial shaded conditions through artificial bee colony," IEEE Trans. Sustain. Energy, vol. 6, no. 1, pp. 198-209, 2015.

[8] L. L. Jiang, D. L. Maskell, and J. C. Patra, "A novel ant colony optimization-based maximum power point tracking for photovoltaic systems under partially shaded conditions," Energy Build., vol. 58, pp. 227-236, 2013.

[9] R. Boukenoui, H. Salhi, R. Bradai, and A. Mellit, "A new intelligent MPPT method for stand-alone photovoltaic systems operating under fast transient variations of shading patterns," Sol. Energy, vol. 124, pp. 124-142, 2016.

[10] M. A. M. Ramli, K. Ishaque, F. Jawaid, Y. A. Al-turki, and Z. Salam, "A modified differential evolution based maximum power point tracker for photovoltaic system under partial shading condition," Energy Build., 2015.

[11] N. Rajasekar, "Solar PV array reconfiguration using the Heating concept Standard deviation and Genetic Algorithm Assessing the feasibility of using the heat demand-outdoor, Kulkarni for temperature function a longterm heat demand forecast," Energy Procedia, vol. 117, pp. 1062-1069, 2017.

[12] S. Obukhov and A. Ibrahim, "Maximum Power Point Tracking OF Partially Shading PV system Using Particle Swarm Optimization," Assoc. Comput. Mach. Moscow, Russ. Fed., pp. 161-165, 2018.

[13] A. Fathy, "Reliable and efficient approach for mitigating the shading effect onphotovoltaic module based on Modified Artificial Bee Colony algorithm," Renew. Energy, vol. 81, pp. 78-88, 2015.

[14] N. Emerson, "Integrating Hybrid Power Source into Islanded Microgrid Using Ant Colony," pp. 5-8, 2015.

[15] A. Fathy, "Recent meta-heuristic grasshopper optimization algorithm for optimal recon fi guration of partially shaded PV array," Sol. Energy, vol. 171, no. July, pp. 638-651, 2018.

[16] R. Ramaprabha, M. Balaji, and B. L. Mathur, "Maximum power point tracking of partially shaded solar PV system using modified Fibonacci search method with fuzzy controller," Int. J. Electr. Power Energy Syst., vol. 43, no. 1, pp. 754-765, 2012.

[17] N. Kumar, I. Hussain, B. Singh, and B. K. Panigrahi, "Single sensor based MPPT for partially shaded solar photovoltaic by using human psychology optimisation algorithm," 2017.

[18] C. Özgür, "A Hybrid MPPT method for grid connected photovoltaic systems under rapidly changing atmospheric conditions," vol. 152, pp. 194-210, 2017.

[19] H. Chaieb and A. Sakly, "A novel MPPT method for photovoltaic application under partial shaded conditions," Sol. Energy, vol. 159, no. October 2017, pp. 291-299, 2018.

[20] Y. M. Safarudin and A. Priyadi, "Combining Simplified Firefly and Modified P \& O Algorithm for Maximum Power Point Tracking of Photovoltaic System Under Partial Shading Condition," no. 1, pp. 181-186, 2015.

[21] F. Salem and M. A. Awadallah, "Detection and assessment of partial shading in photovoltaic arrays," J. Electr. Syst. Inf. Technol., vol. 3, no. 1, pp. 23-32, 2016.

[22] M. Dhimish, V. Holmes, B. Mehrdadi, and M. Dales, "Comparing Mamdani Sugeno fuzzy logic and RBF ANN network for PV fault detection," Renew. Energy, vol. 117, pp. 257-274, 2018.

[23] W. Hou, Y. Jin, C. Zhu, and G. Li, "A Novel Maximum Power Point Tracking Algorithm Based on Glowworm Swarm Optimization for Photovoltaic Systems,” Int. J. Photoenergy, vol. 2016, 2016.

[24] S. Daraban, D. Petreus, and C. Morel, "A novel MPPT (maximum power point tracking) algorithm based on a modified genetic algorithm specialized on tracking the global maximum power point in photovoltaic systems affected by partial shading," Energy, vol. 74, no. C, pp. 374-388, 2014.

Int J Pow Elec \& Dri Syst Vol. 10, No. 4, Dec 2019 : 2182 - 2189 
[25] Syafaruddin E. Karatepe T. Hiyama, “Artificial neural network-polar coordinated fuzzy controller based maximum power point tracking control under partially shaded conditions," IET Renew. Power Gener., vol. 3, no. 2009, pp. 239-253, 2009.

\section{BIOGRAPHIES OF AUTHORS}
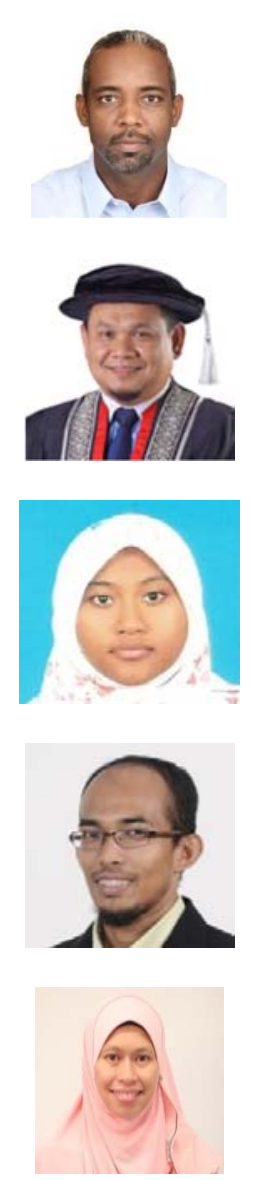

Abdalla Eltigani Ibrahim received his Bachelor of Electrical Power Engineering in Electrical Power Engineering (Hounor) from Alzaeem Al-azhari University, Sudan in 2005, MSc in Electrical Control from Universiti Teknologi PETRONAS, Malaysia, 2017 and he is currently pursuing a $\mathrm{PhD}$ in power optimization in renewable energy. Area of interest: Control Systems, Mechatronics, Renewable Energy, Power Guality, Power Optimization and Electro-mechanical Systems.

Associate Professor Ir. Dr. Nursyarizal Mohd Nor received his Bachelor of Electrical \& Electronics Engineering (Hounor) from Universiti Teknologi Mara, MSc in Electrical power Engineering from UMIST university, $\mathrm{UK}$ and $\mathrm{PhD}$ in Electrical \& Electronics Engineering from Universiti Teknologi PETRONAS, Malaysia. Now he is working as associate professoe in Universiti Teknologi PETRONAS, Malaysia. Area of interest: Power Electronics, Operation \& Control, Electrical Machines, Power SystemsSate Estimation

Dr. Illani Binti Mohd Nawi received hes Bachelor of Electrical \& Electronics Engineering (Hounor) from Universiti Teknologi PETRONAS, MSc in Microelectronics Systems Design from University of Southampton in 2004 and $\mathrm{PhD}$ in Electronics \& Electrical Engineering from University of Southampton in 2018. Now she is working as lectural in Universiti Teknologi PETRONAS, Malaysia. Area of interest: IC Design, Automotive Systems, Robotics, Reliability Engineering.

Dr. Mohd Fakhizan Romlie received his Bachelor of Electrical \& Electronics Engineering (Hounor) from Universiti Teknologi PETRONAS in 2004, MSc from University of Western Australia 2006 and $\mathrm{PhD}$ in power system from University of Nottingham, UK in 2014. Now he is working as lectural in Universiti Teknologi PETRONAS, Malaysia. Area of interest: Power Systems, Electrical Machines, Power Electronic and Electrical Safety.

Madam Khairul Nisak M Hasan received her Bachelor of Electrical \& Electronics Engineering (Hounor) from Universiti Teknologi PETRONAS, MSc in Electrical power Engineering from University of New South Wales, Australia. Now she is working as lectural in Universiti Teknologi PETRONAS, Malaysia. Area of interest: Power Quality, Renewable Energy and Harmonic Power. 